local budgets : the letter of the Ministry of Finances of Ukraine of 19.09.2013 No. 31-05110-14-5/27486]. Available at: https://www.ibser.org.ua/sites/default/files/ lyst_mfu_vid_19.09.2013_udoskonalena_metodyka.pdf

\title{
CONCEPTUAL FUNDAMENTALS OF TRAINING BUSINESS SPECIALISTS OF THE HOSPITALITY INDUSTRY IN HIGHER EDUCATION INSTITUTIONS OF UKRAINE
}

\section{Liudmyla Batchenko ${ }^{1}$ \\ Liliia Honchar ${ }^{2}$}

DOI: https://doi.org/10.30525/978-9934-26-002-5-25

Modern Ukrainian society is in a complex transformational process of various transformations, including educational ones. The humanitarian development of modern Ukrainian society poses new challenges to the domestic education system, the solution of which is ineffective within the existing methodology. Today, the issue of analyzing higher education systems and its compliance in the field of training specialists of various profiles to real time and changing processes in various spheres of society is quite relevant.

The dependence of the competitiveness of the functioning of higher education institutions of Ukraine on the transformational educational processes requires from all subjects of educational activity initiative actions to design mechanisms for radical reform of the entire system of higher education. Transformational processes affecting all aspects of the country's life raise before the education system the issue of changing the educational model, which will expand the concept of humanitarian training.

At the scientific and theoretical level there is a need to introduce scientific and organizational support for an integrative and innovative approach to the process of training students of various specialties for creative industries, including 028 «Management of socio-cultural activities» 241 «Hotel and restaurant business», 242 «Tourism».

In turn, the scientific and organizational support of the integrativeinnovative approach to professional training of students provides a scientific and methodological level of relevance of this problem. The discrepancy between the scientific-theoretical and scientific-practical levels of training of future specialists for the hospitality industry of Ukraine identified in general

\footnotetext{
${ }^{1}$ Kyiv National University of Culture and Arts, Ukraine

${ }^{2}$ Kyiv National University of Culture and Arts, Ukraine
} 
the problem of the need to analyze the educational process in order to improve some of its aspects.

Substantiation of expediency, thoroughness and professional adequacy to the challenges of time of preparation of applicants for certain specialties by graduating departments of higher education institutions should be based on evaluation of results of trend, conceptual and strategic analysis of training of relevant specialists in domestic higher education institutions. areas of business development today and in the near future.

Accordingly, taking into account certain aspects in the process of designing educational training programs for certain specialties will allow the broadest assessment of employment prospects of graduates, their demand in the labor market and ensure the formation of unique learning outcomes through the acquisition of specific professional competencies.

It should be noted that in the specific conditions of doing business and in accordance with the new challenges of the time (in particular the COVID-19 crisis), the market needs for business competencies have changed significantly. According to a survey of managers, executives and business owners in Ukraine conducted by the KSE Business Education Department, more than $80 \%$ of respondents agree that COVID has made adjustments to the skills needs and emphasize the need for wider and deeper interaction of the business sector with higher education institutions. in order to address key issues and make conceptual decisions about the structure and content of skills (as competencies and learning outcomes) that business professionals must have today to ensure the efficiency and competitiveness of business in the short and long term [3].

Today, higher education students in all specialties in higher education institutions of Ukraine are trained according to educational programs developed and approved by higher education institutions in accordance with the approved standards of higher education at the bachelor's and master's levels.

Currently, the training of higher education seekers for the hospitality industry is provided in a significant number of higher education institutions (HSE) in different regions of Ukraine, in particular with the distribution of specialties 241 «Hotel and restaurant business» - 131 institutions; 242 «Tourism» 118 institutions, 028 «Management of socio-cultural activities» - 39 institutions [4].

Despite the wide geography and a significant number of free educational institutions that train applicants in certain specialties, conceptually in terms of changing processes in the higher education system of Ukraine, unfortunately, the key guidelines of educational activities in the outlined specialties are not clearly defined. 
Analyzing the list of specializations distinguished by the first and second levels of higher education within the specialties 241 «Hotel and restaurant business», 242 «Tourism» and 028 «Management of socio-cultural activities», it should be noted that their number in the period 2018-2020 is absolutely insignificant, and the lion's share among all specializations under the name of educational programs (OP) is occupied directly by hotel and restaurant business (84-90\% OP), tourism (68-92\% OP), management of sociocultural activity (75-87\%) without any-what clarifications and ramifications. Separately selected specializations are mostly of a single nature within a particular free economic zone and are unique in other educational institutions, which indicates a kind of uniqueness of such educational programs and applicants who master them [2].

However, it should be noted that for each separate educational program in accordance with the Resolution of the Cabinet of Ministers of December 30, 2015 № 1187 «On approval of licensing conditions for educational activities» as amended in accordance with the Resolutions of the Cabinet of Ministers № 347 from 10.05.2018 and № 180 from 03.03.2020 provisions, must be provided [1]:

- high-quality composition of the project team headed by the head;

- the guarantor of the OP, who will coordinate and be responsible for the implementation of educational activities for each OP with its subsequent accreditation;

- quantitative and qualitative composition of the support group.

This requires the availability of appropriate resource potential of graduate departments of higher education institutions.

Given the analysis of domestic realities of educational activities in specialties, in the context of which provides training for business professionals in the hospitality industry and based on the above regulatory requirements, first of all, consider a very urgent and relevant issue to define and justify the real and undeniable uniqueness of each existing and promising educational programs, which provide or plan educational activities at the department, as a key competitive advantage during the competitive selection for training in certain educational programs.

However, given the variability and dynamism of changes in society, it is necessary to take into account the promising areas of hospitality in its key concepts, which are trendy and economically viable for the hospitality of leading European countries (including Switzerland, Spain, the Netherlands) (Figure 1). 
Riga, Latvia, November 20, 2020

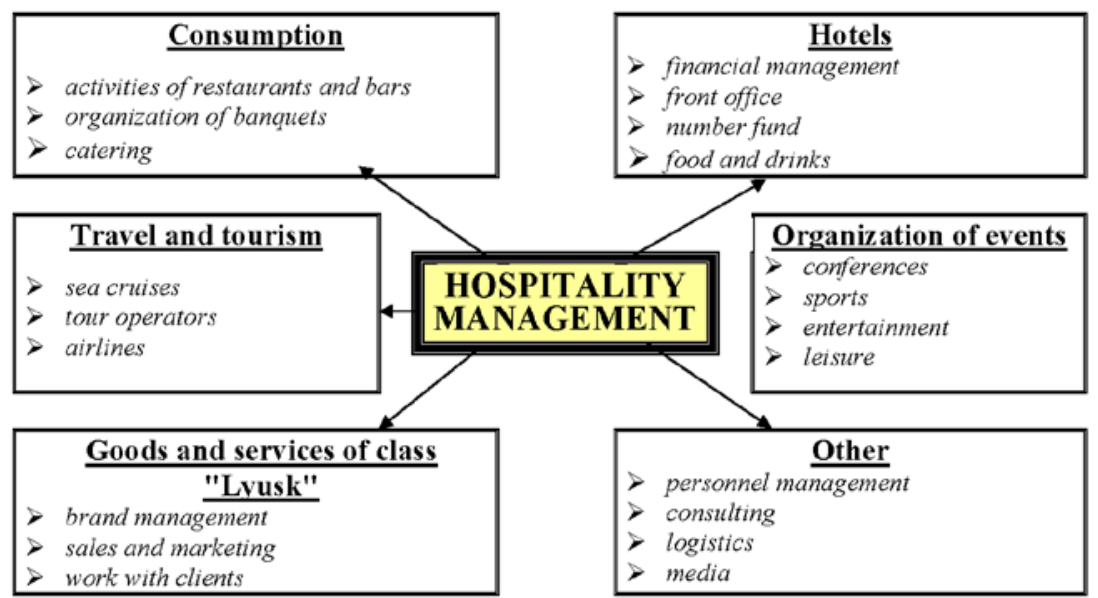

Figure 1. Perspective directions of development of the sphere of hospitality of the leading European countries according to its key concepts

In view of all the above and taking into account the resource opportunities and conceptual visions for the development of hospitality in the short and long term, we believe that all higher education institutions that train business professionals in the hospitality industry to ensure the competitiveness of their graduates in today's labor market., and only then, as a result, their own competitive advantages in the educational environment, should concentrate all their resources on designing unique and time-appropriate educational programs by establishing maximum interaction with real business, using best foreign experience in these areas, acting on anticipating and forecasting the real needs of the business at the time of completion of training by applicants for the first or second levels of higher education.

\section{References:}

1. Cabinet of Ministers of Ukraine (2015, December 30). Postanova № 1187 «Pro zatverdzhennja Licenzijnykh umov provadzhennja osvitnjoji dijaljnosti» [Resolution № 1187 «About the statement of Licensing conditions of carrying out educational activity»]. Retrieved from: https://zakon.rada.gov.ua/laws/show/1187-2015-\%D0\% BF\#Text (accessed 09 November 2020).

2. Information System «Osvita.ua». Retrieved from: https://vstup.osvita.ua/ (accessed 20 July 2020).

3. Kyiv School of Economics (2020). KSE Business Education Survey Presentation. «Changes in the need of business competencies during the COVID-19 crisis». Retrieved from: https://kse.ua/ua/events/?eid=7441\&fbclid=IwAR0yc16vrc 
I16hwXWE-ej4A3V9lLbNxgLQAk10hcMg5aUJTqujDoCryfXP4 (accessed 11 November 2020).

4. The Only State Electronic Database on Education (2018-2020). Derzhavne pidpryiemstvo «Inforesurs» [State Enterprise «Inforesource»]. Retrieved from: https://registry.edbo.gov.ua/ (accessed 09 November 2020).

\title{
INFLUENCE OF THE COVID-19 PANDEMIC ON THE ECONOMIC RELATIONS OF UKRAINE WITH LATVIA, LITHUANIA AND ESTONIA
}

\author{
Maryna Kachanovska ${ }^{1}$ \\ Sergey Yakubovskiy ${ }^{2}$
}

DOI: https://doi.org/10.30525/978-9934-26-002-5-26

The Baltic States are of geopolitical interest to Ukraine in the development of Baltic-Black Sea cooperation and in the pursuit of their own political and economic goals. Ukraine is constantly improving its foreign economic relations with Latvia, Lithuania and Estonia. Latvian-Ukrainian economic cooperation has good potential for development. Today, there are all prerequisites for the further development of bilateral economic cooperation, especially given Ukraine's progress towards EU integration.

The global Covid-19 pandemic has significantly affected trade relations between Ukraine and these countries, so it is important to assess the negative effect of the pandemic on the balance of goods and services, as well as the dynamics and volume of foreign direct investment between selected countries.

Table 1 presents data on trade relations between Ukraine and the Baltic States for January-September 2019-2020. It should be noted that in 2020, due to the pandemic, the volume of Ukrainian exports decreased compared to the same period in 2019. Ukrainian exports to Latvia and Estonia decreased by almost 30\%, but to Estonia by less than 1\% Imports also suffered from the current situation, however, if imports from Latvia and Lithuania to Ukraine decreased by $10.7 \%$ and $26.9 \%$ respectively, Estonia, on the contrary, exported goods to Ukraine in 2020 by 34\% more than in 2019.

Ukraine shows a positive trade balance with Latvia, as Ukrainian exports exceed Latvian imports to Ukraine. Ukraine's trade relations with Lithuania have always recorded a negative balance. The Ukrainian balance of goods

\footnotetext{
${ }^{1}$ Odesa I. I. Mechnikov National University, Ukraine

${ }^{2}$ Odesa I. I. Mechnikov National University, Ukraine
} 